\title{
Kære studerende
}

Dorte Lindelof ${ }^{1}$, Institut for Odontologi og Oral Sundhed, Aarhus Universitet

\author{
Ey Danmark, hvad sker der for dig?
}

Jeg savner dig, jeg vil ha' dig tilbage ligesom i de gamle dage

Hvor en spa'e var en s-, yo

Jeg vil ha' dig tilbage ligesom i de gamle dage

Hvor en fri fugl var fri, og hvor man mente, hva' man sagde

Ey Danmark

Jeg savner dig, jeg freaking fucking savner dig ...

(fra "Gi' mig Danmark tilbage", Natasja, 2007)

\section{Kære studerende}

Jeg savner jer, jeg freaking fucking savner jer. Det betyder noget for mig, at vores relation i løbet af 2020 som konsekvens af COVID-19 blev forandret, og jeg mærker, ligesom afdøde Natasja, en insisteren på, at jeg vil have det mistede tilbage. Arh, kom nu for fanden! Jeg har før oplevet følelsen af at savne jer, fx efter afslutningen af et intenst undervisningsforløb eller et længerevarende vejledningsforløb ifm. en skriftlig opgave. En følelse af savn og tomhed.

Med ét slag, en dag i marts, lå landets gader tomme hen, og al undervisning gik online. Jeg har i den akutte nedlukningsfase og i den efterfølgende mere reflekterende og eksperimenterende fase erfaret, at det er muligt at lave god onlineundervisning - aktiviteter, hvor I og jeg arbejder sammen om at undersøge et specifikt fagligt stofområde, og hvor læreprocesser finder sted. MEN noget er gået tabt. Jeg oplever som underviser, at jeg har sværere ved at opnå kontakt med jer. Få af jer studerende aktiverer jeres kamera trods mine opfordringer. Mine fantasier om hvorfor får frit løb, og jeg føler en afmagt ift. dels at sikre relationen mellem jer og mig og indbyrdes mellem jer og dels at understøtte jer i en oplevelse af, at læringsrummet er relevant og trygt. Jeg oplever ensomhed - en ensomhed, som forstærkes af jeres deaktiverede mikrofoner (ja, jeg ved godt, at vi - fordi det ellers støjer - har lært jer, at jeres mikrofon skal være slukket, medmindre I ønsker at sige noget).

Der er ikke en lyd ud over mig, der taler. Ikke et forsigtigt spørgende grynt eller et "mmm", der forsikrer mig om, at I bearbejder stoffet. Ikke et host eller et gab, der lader mig kende til jeres tilstedeværelse. Ensomhed er ikke den eneste følelse forbundet med fraværet af ansigter og lyd - usikkerheden følger med: Er I mon optaget af det faglige stof og af aktiviteten, vi er i gang med? Oplever I meningsfuldhed i undervisningens faglige fokus og mine didaktiske valg? Usikkerheden betyder, at jeg kommer til at tale mere, end jeg sædvanligvis ville gøre i en undervisningssituation - med den mulige konsekvens, at I blot i ringe grad delagtiggøres i stoffet og måske endda falder fra. For at vide, om I er der, og nok også for at dæmpe min egen angst for måske slet ikke at være

${ }^{1}$ Kontakt: dlindelof@dent.au.dk 
her, hvis I ikke er der, er jeg begyndt at indlede undervisningsseancer med en forventningsafstemning - bl.a. har jeg bedt om aktivering af jeres kameraer og argumenteret for vigtigheden af dette med henvisning til, at jeg som underviser har brug for respons fra jer for at levere en undervisning, der sikrer jer et tilfredsstillende læringsudbytte. Når jeg har efterspurgt jeres refleksioner over min forventning og de perspektiver, der ligger til grund for denne, har enkelte aktiveret deres kamera, mens de fleste skærme er forblevet sorte, ligesom mikrofonerne er forblevet deaktiverede. Det er svært at tale om vores fælles oplevelser af onlineundervisningen, og jeg ved så lidt om, hvad der rører sig hos jer. Jeg har indtil i fredags ment, at jeg i onlineundervisningen fremover ville benytte mig så lidt som muligt af andre digitale værktøjer, men i stedet fokusere på spørgsmålet om, hvorledes analoge værktøjer inddraget i onlineundervisningen kan medvirke at understøtte relationer og dialoger i onlineundervisning, herunder medvirke til at skabe positive, trygge og meningsfulde onlinerum for læring. Så skete der det, at jeg i fredags underviste en gruppe studerende, som jeg ikke kendte på forhånd. Emnet var "psykodynamisk tilgang til læring og trivsel i studie- og arbejdsliv". For at anskueliggøre negative tanker og følelsers betydning for læring og trivsel lavede vi en refleksionsøvelse, hvor vi frit associerede med udgangspunkt i vores erfaringer i relation til emnet "onlineundervisning". Idet vi talte sammen på denne måde, og måske også fordi vi ikke før havde erfaret at være sammen i en online-undervisningssituation, og fordi vi nu var fysisk tilstede sammen, opnåede jeg nye erkendelser og en nuancering af min forståelse af egen og studerendes tilstedeværelse i onlineundervisning. Flere studerende fortalte om deres begrundelser for sjældent at aktivere kameraet - bl.a. om ikke at ville skille sig ud blandt studerende med sorte skærme og om ønsket om at bevare sin rolle og identitet som studerende fremfor at deltage som privatperson med opvask og en kæreste i baggrunden. En anden pointe, de studerende fremhævede, var, at de i undervisningen slet ikke havde interesse i at se andre studerendes billeder, som de så som forstyrrende elementer og derfor valgte "speaker view", altså kun billede af forelæseren. Idet de studerende og jeg talte sammen, blev jeg opmærksom på de studerendes og underviserens forskellige positioner i undervisningsrummet. De studerende og underviseren har altid opholdt sig i læringsrummet af forskellige årsager, deltaget ud fra forskellige hensigter og varetaget forskellige roller og ansvarsområder. Når jeg er optaget af jeres manglende aktivering af kameraet, handler det også om min trang til at se jer. Når jeg argumenterer for, at aktivering af jeres kameraer vil styrke jeres læring, er det således en forståelse, der kalder på nuancering, for måske er argumentet mest grundet i mine behov.

Jeg ønsker ikke at vende tilbage til det, vi havde før. Vi har brug for onlineundervisning, det har COVID-19 lært os, og vores erfaringer har vist os, at onlineundervisning er yderst meningsfuld, når den praktiseres klogt. Jeg vil have relationen mellem jer og mig, og mellem jer indbyrdes, tilbage. Disse relationer vil styrkes, idet vi bliver fortsat mere erfarne i at være og lære i onlinelæringsrum og ved, at analoge og digitale metoder kombineres på klog vis. Relationerne styrkes også ved at fortsætte dialogen om psykodynamiske aspekter af læring og trivsel i undervisningssituationer. I løbet af 2020 er jeg blevet bevidst om netop psykodynamisk tænknings potentialer, ikke blot i undersøgelser af onlineundervisning, men af enhver læringssituation - også formatet "undervisning med fysisk fremmøde". Jeg er blevet bevidst om, hvor lidt jeg, trods solid undervisningserfaring og stærke pædagogisk-didaktiske kompetencer, egentligt ved om jeres erfaringer også inden for dette så velkendte format. Lad os lære sammen.

Bedste hilsner

Jeres underviser 


\section{Betingelser for brug af denne artikel}

Denne artikel er omfattet af ophavsretsloven, og der må citeres fra den.

Følgende betingelser skal dog være opfyldt:

- Citatet skal være i overensstemmelse med "god skik"

- Der må kun citeres „i det omfang, som betinges af formålet"

- Ophavsmanden til teksten skal krediteres, og kilden skal angives ift. ovenstående bibliografiske oplysninger 